\title{
A SHORT DISCOURSE ON ART
}

Mr. Onabolu leaves for Europe on $2^{\text {nd }}$ May 1920; and while there he will gladiy receive and executive commissions for Portrait paintings etc, and will undertake to send such executed Orders to any part of the world that it may be required. His London Address is as fellows:

\author{
Aina Onőbolu \\ C/o Principal \\ St. Johns Wood Art Schools \\ 29 Elm Tree Road \\ London N.W.S.
}





\section{PREFACE}

In this small pamphlet Mr. Onabolu is giving a short discourse on Art as a sort of introduction to his own words. In it he does not lay claim to any pretentious of an expert. But his motive is that of a student full of enthusiasm and with all his life and energy in the work which he loves. Still it will be found that Mr. Onabolu is correct when he discusses such technical topics is for instance, light and shade, focus and perspective.

What makes the pamphlet necessary is the appalling lack of interest (expressing it mildly) on the part of the majority of our people - the educated class not excluded - to appreciate a painted picture as something superior to an ordinary photograph or even coloured photograph. If, therefore to our European friends Mr. Onobolu seems to dive into details which may appear unnecessary in their own case, his treatment of the subject will find ample justification in the fact that the majority of his readers are unacquainted with works of Art.

There is a peculiar interest attaching to Mr. Onabolu and his words which would have been the same if he were a European as he is an African - the fact that he had never received any training in Art. The amount of success which has attended his efforts will on the one hand be more appreciated by everybody and on the other hand be of greater value to Africans because his genius is essentially of Africa.

There is no greater medium of expression of nationl life and character than Art and no one but Africans can fully express her joy and sorrow, her hopes and aspirations, and her changing moods and passions. In this respect a great role awaits Mr. Onabolu - the interpretation of Africa to the outside world.

What am I

"But a child -

"A child crying in the night

"And with no other language

"But a cry."

A. O. Delo Dosumu

$27^{\text {th }}$ April, 1920. 

P1.

\section{A SHORT DISCOURSE ON ART}

"Talk of a Genius baffled. Genius is master of man. Genius does what it must, and Talent does what it can."

- Meredith

The object of this picture exhibition is to show to the public in general some of the pictures I have been able to paint without the aid of an Art master and thereby prove that God is impartial in His endowments of various talents to mankind. The Art in this catalogue is used only as a term specially applied to distinguish painting and sculpture from many so called arts because, now-a-days many things have been adorned with that title to which the term science or skill would be more applicable.

High Art, the lofty and the grand has been said with truth that it can be produced by one endowed with the talent, one capable of deep feeling and possessing refined taste; and that by such the impressive scenes of great historical events and the conception of the poet are represented in painting more fully that by any other medium.

We are all fully aware of the fact that from time immemorial the West African Negro has often been reproached with his failure to develop any high form of civilisation that he has never painted a picture or sculpted a statue and that

P2

-this reproach like an irrefutable fact has so long remained, as it were, ineffaceable. Some cherish the opinion that nature rather than the West African Negro, is primarily to blame and that his environment is entirely against him. Others say that he lacks aspiration after noble objects, he possesses fine brain, but does not develop it , that he is easily satisfied with little things and does not learn to admire rightly. With all due defference to to the former I may say, I, in some respects agree with the former but I entirely disagree with the latter. I believed as a writer once puts it, viz:- "No one is born into this world whose work is not born with him. There is always work and tools to work - withal for those who will." I 

know many young men in this country with talent of some sort, "who for want of ambition and encouragement or both, do not develop their powers, but leave their talents to remain dormant, forgetting that some day they will be called upon to give account of the use they made of the given talents; and that the penalty of dereliction of duty can neither be escaped nor avoided. The pictures that are being exhibited here today are only specimens of nearly two hundred pictures that are the outcome of incessant labour under adverse circumstances, while spending most of my time in the Government offices - in the Marine and in the Customs Departments; and I up to this time studied under no Art Master, except under the great teacher - "experience"- whom Cicero called the great tax-gatherer. I derived great benefit from my study of nature who has always been kind enough to unravel to the eyes and mind of

P3

- every art-student possessing the faculty of seeing nature in her true beauty. Unlike the art-student who is led to the study of nature by the academic training like a horse that is led to the fountain but cannot be made to drink.

I am greatly indebted to my European friends and lovers of the advancement of natives in Nigeria, such as Sir William Macgregor, Mr. and Mrs. Moseley, Dr. and Mrs. F. G. Hopkins, Mr. E. O. Commings, His Honour R. J. S. Ross, The Honourable T. F. Burrowes, Mr. J. M. Dunlop, Lt. Commander J. Percival, Mr. W. K. Duncrombe, Mr. E. Mumby, His Hon. G. L. Temple and many others who have encouraged me either by giving me commissions to paint or by giving me such hints as helped me on in my toilsome and up-hill road to the world of art.

Among native I am also thankful to such men as Dr. Randle, Revd. W. B. Euba. The Hon. S. H. Pearse. The Hon. Kitoyi Ajasa. The Hon. Adegboyega Edun, Messrs. D. A. Taylor, Da Rocha, J. H. Doherty, Barrister J. Egerton Shygle, Mr. Herbert Macaulay, C. E., Dr. \& Mrs. M. T. Ogunmefun, Mr. J. A. Odufunade, Mr. S. Samuel, late Mr. E. A. Caulcrick, late Mr. \& Mrs. C. A. Robbin, late Mrs. Spencer Savage, the Editors of all local papers and many others who encourage me by their kind words and by giving me commissions to paint portraits of either themselves or of their dear ones. 

Let us consider what is the use of pictures, what constitutes a good picture and how to get it.

Let us pause for a while and think for ourselves what effect this world with all the beautiful things around us would have had on use if we had no means of producing a picture - the image or representation of people or places about which we had read or hear; what notion, oh! varied and indefinite notion we should have had of our great historical events, the habit of our ancestors or ancient people, the habits of foreign people both ancient and modern, the conceptions of poets, the visions seen and told in the Holy Writ, the birth of Christ in the manger, the find of Christ in the temple, the Crucifixion, the descent of our Lord from the Cross and His glorious resurrection and ascension - these of all these - we could have had no definite idea had there been no artist - painter of fine art endowed with deep feeling and strong imaginative faculty. Take again for instance the influence of such picture as the Battle of Jutland, wherein the superiority of the British Navy to that of the Germans during the last great war in which every nation of the world took part had and still has upon the minds of British and Foreign peoples. Think again about the picture depicting a scene that took place near Compeigne during the famous retreat from Mons on $1^{\text {st }}$ September 1914. In this picture Mr. Matania is successful in perpetuating upon canvas the unconquerable British valour which would be handed down to posterity. This picture will ever serve to remind British youth from generation to generation of

P5

-the great deeds which their heroic ancestors had performed before their times.

Here in Nigeria our ancestors had in their own way performed great deeds before our time, our kings had ruled majestically although in some measures in a misdirected manner as has always been the case in the history of any nation in her primitive state. Our fore-fathers had shown valour in the fields and our statesmen wisdom in their legislation. But have we any records of their glorious deeds and achievements? I answer emphatically, No! If any there be they are like words written on the surface of waters all of which in a moment vanished away. Why? It is because we are apt to be satisfied with little thing which is the result of little efforts and we never venture to see greatness in little things; not that we cannot see it we try to do so. Had we but tried as a race we should have found among us 

our Watts and Boultons, our Marconi and Edison if only we learned not to despise little things. Some of us young men read about these men but we never try to be like them. When we go to the Concert and Entertainment Halls we discuss only the voice of the singer and look for action that incites laughter and we discuss the dress of the actor but not dive below to see what is in the character of the play, whether it is elevating or demoralizing, whether it is or not in keeping with the religion we embrace and profess.

Now in this country, it is a blessing that we begin to value the portraits of our parents, of great men, and of those who are dear to us. Yet

P6

- there is something wanting and that is, that we have not learned to distinguish painting from coloured photograph or the requisite qualities that make a good picture. If some of us were asked why they passed a portrait of some one's that they knew for a good one they would say because they found all the features and details - veins, wrinkles, and every individual hair of that one's face as vividly as in life, therefore they conclude it is good picture. I may here ask this class of people to reason with me a little while that we may in future be better able to judge and admire rightly what a good picture is.

The word picture in this catalogue is used to denote the representation of objects as they would appear from an assumed point of sight. This definition would at once suggest to the mind of my reader the idea of perspective and of focus; now perspective being a compound of the Latin words per, through, and specto, to view; i.e. to see through; therefore perspective is the art of drawing several objects as they world appear if traced upon a glass or transparent plane; and here a line may be drawn between perspective and geometry: perspective shows objects as they appear and geometry shows them as they are in reality; and focus means a point of concentration. Now no picture should pass as a good one that is totally void of either focus or perspective: for example, take a walk into the Glover Memorial Hall there you will find two pictures hung side by side; one of the late Dr. Bailey's and the other of the late Honourable Sapara Williams,' B. L., C. M. $\mathrm{G}$. The former is 

- totally void of a focus, void of gradation, of tone, breath, and harmony. Here all the fingers of Dr. Bailey's hands spread upon his lap as rigidly and lifeless as those of a dead man; the petals of the flowers and its spray in the back ground are so forceful and hard in their outline that they compete with the sitter. This should not have been passed as a good picture of that noble man whose portrait should be of public interest. This is entirely not the fault of the sitter but of the photographer. The latter picture though comparatively much better yet it is somewhat too weak and feeble looking about the head to be quite desirable.

Immediately after the death of the late Bishop Johnson, meetings were being held in many central and public places by men and women of the upper and middle class to consider what could be done to perpetuate the memory of this great man. The men then resolved to have a big monument with fountains put on a central and conspicuous part of the town. The Lagos Christian women resolved to have the late Bishop's portrait painted in England that may be handed down to posterity and to perpetuate his memory. The women did something tangible although their efforts were misdirected; instead of a painting they have got a coloured photograph and the colour of the Bishop's face and hands made him look like an Arab; a photograph or coloured photograph, as far as I know can never last as long as a painting. Another portrait of this description is that of the late Mr. A. C. Willoughby that was unveiled at the Glover Memorial Hall about twenty six years ago, which has

P8

- become a ruin and had been brought to my studio for restoration about six months before the burning of the Town Hall. When the enlarged coloured photograph of the late Bishop came to the hands of the women I was called upon and asked to take it up and retouch it. I then replied frankly that the picture would be better left alone; that I would not mind to paint my own portrait of the Bishop if they like.

Now I am glad that today, I have among my other pictures that of the late Bishop Johnson which I have painted on my own accord.

It is not the object of this discourse, however, to do more than to draw the attention of those of my readers who feel their incapability to distinguish a good 

picture from a bad one and who may want to know the use of it. I cannot here dilate upon the subject, but it must be borne in mind that to be able to realize and appreciate a good picture on e must learn something about art, just as it is that to be able to enjoy music one must know something about music.

Owing to the shortness of time and space at my disposal I must now give as briefly as possible the history of art, which in itself, would take several volumes to give an adequate account.

Since the prehistoric period the human mind has been seeking the means by which to give expression to its feeling and this has been found more satisfactorily in painting than by any other medium, be it sculpture, music or language.

\section{P9}

The earliest history of art has its origin in Egypt and we all know that Egypt is the earliest civilized nation of antiquity. Their first attempts were crude, progress was very slow, keeping pace with the development of the human mind.

Painters and sculptors were confined to sacred subjects; for art was considered to be too exalted to be devoted to others; in Egypt it was a sacred calling, and its professors men trained to the service of religion, and bound by strict rules from which they dare not swerve; by adherence to the rules which for centuries established certain forms prohibiting any advancement towards beauty, they became mechanical. The monotonous adherence to fixed forms in modern Chinese painting has its prototype in the production of the ancient Egyptians, whose conventionalities became characteristic, probably from policy in the priesthood to inspire awe and wonder by making the representations of their deities different from ordinary humanity; therefore they never advanced beyond stiff postures, absurd violation of all consistency in drawing and perspective they, like our people here in Nigeria, were putting a front-view eye in a profile head, the feet and hands twisted aside in a figure standing full front; dislocated necks with muscles out of proportion and every limb in stiff postures.

The monuments of Babylon are better than the Egyptians as they were made to resemble nature. From this condition art advanced and attained its highest 

perfection in ancient Greece; at first there 500 B. C. It was greatly influenced by the old

P10

Egyptian character. The perfection of later Greek art is due to their public spirited enthusiasm. With them art was a glory and its practice sacred. An artist in ancient Greece was looked up to as a superior being honoured as the bearer of a divine gift, devoted to the gods and the community. The arts were the breath of life with the Greeks and Cicero observes: nothing could have compensated them for the loss of such works as the Venus; it would have been felt as a public calamity. However up to the age of Raphael the main function of pictorial art was confined to illustrations of Holy Writ, and the preservation of the likeness of persons after their death. Before the sixteenth century there were no landscape painters in the true sense of the meaning, and no animal pictures, not still life, no flower paintings.

Art fell when Greece fell and Rome rose. The Roman conquerors had no such love for art as the ancient Greeks. They only used it for a luxury, though they employed Greeks, it was only for adornments and commemorations of their victorious achievements. During ages of conquest and barbarism, it had passed away from Greece and almost sunk to the low level of its primeval condition in Egypt.

However under the influence of the church, when Christianity was established it revived in Italy. Leo X, and Julius II, were chief patrons, when Leonardo Da Vinci, Michael Angelo and Rafael flourished. So we find that in Greece, where art was

P11

most perfected, it was all in all to the entire community - unlimited honour, unlimited rewards were given the great art-masters. Again in Italy with the church and state for its support, the supreme Pontiff, his Cardinals, the great, the learned and most opulent, we see the result of combination, genius, devotion, enthusiasm and patronage. There in other European nations, as Holland, Germany, Flanders, and Spain appeared several most extraordinary geniuses, who were called the old masters. 

As I have already observed, there were no landscape paintings before the sixteenth century; all the early landscape painters up to this time and even later, were utterly void of perspective and focus; in so much that in the year 1750 William Hogarth the famous English painter drew an amusing satire on the error of perspective which many of the artists of that time, who were not conversant with the science of perspective were frequently committing; and thus the witty painter punished their ignorance. But let me here remind my reader that portrait painting is certainly the highest and the most difficult of Pictorial Art, requiring in its extended practice, at least, subordinate education in all other branches. "How often, for example, says John Burnet, F. R. S., "do we perceive in those who draw landscapes the incapability of drawing the human figure with any degree of correctness; this arises entirely from careless drawing in the first instance. A tree may be imperfectly drawn yet look sufficiently true to please most spectators; but the human figure possesses propor-

P12

-tions, the want of which can be easily detected but had we an opportunity of comparing the tree with original in nature, we should discover the resemblance to be equally imperfect, for all eye capable of drawing correctly, can draw any object presented to it, whether simple or complicated."

It is now nearly two hundred years ago, through the instrumentality of the good Captain Coram and the co-operation of such men as George Frederick Handel, the world-renowned musician, William Hogarth, Sir Joshua Reynolds, Allan Ramsay, Richard Wilson, and other representative painters of the period that the way became open for a national academy of art in London. Before this time there had been several attempts to provide analytical training to the embryo artist; but for want of interest and fund all ended in failure. Great credit is due to Sir James Thornhill as he did all that was humanly possible to foster the growth of English art. He established a drawing school in his house in the Piazza Covent Garden. He loved his art and did much to encourage it. There was also Hogarth's academy, the immediate predecessor of the Royal academy opened in 1734. 

A Royal academy was advocated. The Duke of Richmond opened his gallery of antiques in Spring Gardens to artists. The Society of Artists became prosperous and its exhibition held in 1761 in Spring Gardens brought in $£ 650$. To the cata-

P13

-logue of this exhibition held in 1762 Dr. Johnson wrote a preface. "All, he says "cannot be judges or purchasers of works of art. Yet we have found by experience that all are fond of seeing an exhibition." The society which included Reynolds, Gainsborough, Zoffany, Wilson, and West obtained a Royal Charter in 1765, and became the Incorporated Society of Artists of Great Britain. Some time later, the greater members of this Society feeling that the condition of things were unsatisfactory resigned; and presented forthwith a Memorial to the King invoking his aid in the foundation of a "school or academy of design for the use of students in the arts."

George III, acceded to the request of another delay . The Memorial was presented on November $28^{\text {th }} 1768$. On December $10^{\text {th }}$ of the same year the document known as the instrument was signed by the King, and the Royal Academy, "a Society for promoting the Art of Design," came into being. The members of the Academy congratulated themselves upon having Sir Joshua Reynolds the Devonshire boy, who as a portrait-painter has never been surpassed, as their first President of the Royal Academy. On January $2^{\text {nd }} 1769$, the first public assembly of the Academy was held, and Sir Joshua Reynolds then delivering the first of his celebrated Presidential Discourses said: "Gentlemen, an Academy in which the polite arts may be regularly cultivated is at last opened among by Royal munificence. This must appear an event in the highest degree interesting not only to the artist, but to the whole Nation."

\section{P14}

The first exhibition of the Royal Academy, to which good number of artists contributed, was held in Pall Mall on April 26, 1769, and contained 136 paintings.

To George III, belongs the credit of helping the Institution by his personal popularity, by his insight, by his purse. He guaranteed any deficiencies between the profit from the exhibition and the expenditure incurred on the Schools and charitable donations. He paid the precise sum of $£ 5116.11^{3 / 4}$ out of his own Privy 

Purse for the purposes, his last payment being made in 1780. the King was a real patron of art.

The first Exhibition held at Somerset House contained 489 pictures by the most famous painters of the latter part of the eighteenth century - Reynolds, Gainsborough, Richard Wilson, Benjamin West, Stothard, Beechey, Cosway and the Loutherbourg. The Exhibition was a great monetary success. George III set the fashion. The galleries were crowded. The receipts for the season amounted to $£ 3069$ as the Exhibition was then being held every year, the amount realized in 1780 was $£ 1700$ more than what was realized in the previous year.

Let us now come home to ourselves in Nigeria. What have we done to promote Art or Science? Our Geledes, Alapafajas, the Ibejis, (sculptures) and our drawings are still crude destitute of Art and Science; our canoes remain as they were since the day, when first they came into use without the

\section{P15}

-slightest improvement. Why! Are there not among us young men, or men of brain capable of improving our condition and surroundings? There are, I say emphatically a good number of youngmen among us with fine brains, but for want of self application and perseverance they cannot bring themselves forward, and therefore they remain unknown.

Youngmen, let us wake up to duty; on us depends the future of Nigeria. Let us bear in mind that whatever we do in every moment of our life - be it good or bad it is like a seed sewn, which must inevitably yield fruit after its kind. If we are industrious, we shall reap the fruit of industry, if we are indolent we shall reap the fruit of indolence. Let me here quote for your reflection the golden words of William Turner, one of the greatest English landscape painters; he says:

The lamp of genius though by nature lit, If not protected, pruned and fed with care Soon dies, or runs to waste with fitful glare.

Rev. Swain also says: "If genius must be called a gift from Heaven" and a light divine," it must also be said to be the "power of taking pains." 

We had gold, ore and bitumen in our land. We never knew we had them there until Europeans, by their power to discern greatness in little things, by their inventions and industry, came to our land, discover, and brought them out of the earth. 
